\title{
Guest editorial: special education and the deviant child in the Nordic countries - the impact of Foucault
}

\author{
Julie Allan* \\ School of Education \\ University of Birmingham \\ Email: j.allan.1@bham.ac.uk \\ ${ }^{*}$ corresponding author \\ Bjørn Hamre \\ Danish School of Education \\ Aarhus University \\ Email: bjha@edu.au.dk
}

Keywords: Foucault, disability studies, disability history, special-needs education, Nordic countries

This special issue considers the impact of the work of Foucault on special education and on constructions of the 'deviant child' within the Nordic countries, and it comes at a point at which we are seeing a global expansion of what Sally Tomlinson (2012) has called a 'Special Educational Needs industry', accompanied by rapidly growing assessment and accountability systems (Stiggins, 2002; Sahlberg, 2007). These systems are validated and maintained by an educational testing profession (Ydesen, 2011; Ydesen et al., 2013) that promotes a scientific taxonomic discourse over teachers' subjective judgements to the point that, as Axelsson, writing in this issue, notes, 'the tests live their own life'. The 'deviant child' appears currently to be a valuable commodity and more and more children seem to be captured through diagnostic practices such as 'psychopathologization' (Harwood \& Allan, 2014), whereby children's behavioural problems are becoming increasingly reassigned to categories of mental disorders and institutional gaming practices (Waitoller, Artiles \& Cheney, 2010; Artiles et al., 2010) that encourage professionals to mark individual children in ways that guarantee a continuity of heterogeneity (Bogard, 2000). Inherent learner differences associated with race and poverty are also caught within the web of deviance through practices of genetic determinism (Gillborn, forthcoming; López, 2014) and a 'new eugenics' of assessment (Gillborn, 2010). These cultural practices are more covert but are presented and taken up by politicians and others as part of a scientific discourse. In such a context, it seems 
all the more important to interrogate and revisit current understandings and to acquire new conceptual tools to do so.

The work of the philosopher Michel Foucault has already proved invaluable to many education scholars for analysing how practices of subjectification and disciplinary regimes (Foucault, 1977) create the 'fleshless passive body' (Hughes, 2005, p. 84), complicit, but also capable of resistance. Foucault's incitement to question what we think we know and to realize that we are freer than we feel (Foucault, in Martin et al., 1988) has encouraged a search for 'unforeseen untried possibilities in our history' (Rajchman, 1995, p. 14). As McWhorter (2005) explains,

The point here, I think, is not to feel bad about the injustice or the suffering in the world ... The point is to pull up short before the possibility that what you thought was true might not be, that what you thought was normal or natural might be the product of political struggle, and to start - from just that place - to think, which means to question, to critique, to experiment, to wonder, to imagine, to try. (p. xvii)

Many Scandinavian scholars have taken inspiration from Foucault. In particular, the Danish historian Birgit Kirkebæk's historical analysis of the normalization ideology has especially been influenced by Foucault's archaeology and genealogy. Her analysis of the institutionalization of the feebleminded has, in turn, influenced the Norwegian way of interpreting disability studies and Foucault has been subsequently applied to fight the case of the feebleminded and other institutionalized groups during the twentieth century. The Nordic orientation to Foucault's work has been in relation to issues of emancipation of the institutionalized, rather than on the issues of subjectification related to questions of ethics and rights of disabled people. These studies of the constructions and accommodations of the deviant child have been quite separate from Foucauldian analyses of education in general, the latter having tended to examine how subjects have been governed in education. The discourses associated with disabled people have been shifting over the last 20 years from concerns with normalization to issues of rights and inclusion, but this does not seem the have affected the ways in which Foucault's ideas have been taken up. There are, however, some exceptions and some of the contributions in this special issue offer analyses that position the disabled subject as being capable of acting and of challenging forms of subjectivization and control.

The articles that make up this special issue offer a strong and coherent narrative on time, place, and personhood. Time is addressed through an historical and Foucauldian reading of past educational and diagnostic practices which gives us an opportunity to explore the ways of speaking about pathologies and of how psychology and medicine have made it possible to 'tell the truth' (Foucault, 1976, p. 74) about these pathologies because he understood that they possess the truth about medicine and psychology. Foucault, in his analyses, offers some substantial theoretical tools that could enable us to understand current contexts more fully. The particularity of the space of the Nordic countries is elaborated within the articles covering Denmark, Norway, Sweden, Finland, and Iceland, and the differences between countries provides a mirror with which to reflect upon other European contexts as well as back on the Nordic countries themselves. The changing nature of the space of the school is also a feature of the articles and is an extremely important consideration. Sjöberg (2014), reflecting on the radically changed space of the school, notes an increasing imperative on the student for visualization and documentation of learning and indeed engagement within school. The physical space, thus, becomes subordinate to visual and documentary representation. The subject of the child 
is consequently radically affected by an altered symmetry between adults and children, leading to an intensification of individualization and the development of a self-regulated child (Beach \& Dovemark, 2011). We see, then, the emergence of the 'regulated child' (Vallberg Roth \& Månsson, 2009). The contributions consider personhood and constructions of the human subject through the exploration of themes of empowerment, transgression, and subjectification.

The first of the articles reflects on the Danish context and considers 'The subject of exemption - through discourses of normalization and individualization'. Here, Bjorn Hamre, Tine Fristrup, and Gerd Christensen trace the changes over time in the conception of the deviant subject and highlight the lack of convergence, until relatively recently, between discourses of special-needs education and of education more generally within Denmark. Hamre and colleagues' analysis shows how much the former has to learn from the latter, especially where Foucauldian research is concerned. Thom Axelsson's contribution, 'Intelligence testing, ethnicity and construction of the deviant child: Foucault and special education', shows how IQ testing was used in Sweden as a tool for controlling social behaviour. Axelsson illustrates the devastating consequences of this through the proliferation of discourses, initiated by Ohlander, about the deviance of children considered to be 'Tattare' (i.e., Scandinavian Travellers) and the subsequent considerations, associated with eugenics, of how such populations might be controlled. In 'Why Michel Foucault in Special Education Research?' Hege Knudsmoen and Eva Simonsen take up Foucault's later work on ethics to trace ways in which constructions of the deviant child were validated in Norway and in other parts of Scandinavia. In so doing, they highlight the fruitfulness of such a perspective even though it is one that is pursued to only a limited degree within special education. Lauri Siisiäinen tells of the competing rivalries over the construction of the deaf child fought by oralism and manualism in 'Foucault and deaf education in Finland'. These respective German and French traditions spread across Scandinavia, but in Finland, Siisiäinen notes, oralist practices prevailed together with the idea of the deaf child as a sensual and perceiving subject. Manualism, oralism's opposite, was constructed as a dangerous and desubjectivizing force, with the eye represented as the animalistic and unstable subject. Bjørn Hamre, in his article, 'Diagnosing, special education and 'learnification' in Danish schools', uses Foucault to document the twin tracks within the Danish educational system of learning and diagnosis, and demonstrates this specifically in the discourses of educational psychologists. Hamre depicts the diagnosed or deviant child as an entity that lives in the shadow of the ideal type of the learner, governed by the 'maybe-ability' imperatives of the school. Finally, a broader perspective on the incursion of democratic and inclusive education is given by Ólafur Páll Jónsson, drawing on Foucault's notion of the gaze and referring specifically to Iceland. Páll Jónsson reminds us of the powerful role of ideology in the consolidation of the powerful concept of abnormality. He also, however, makes a convincing call for a different kind of education which allows for, and even privileges, an active subject through inclusion and democracy and, citing bell hooks (1994), promotes the notion of the school as a site of ecstasy. It is indeed salutary to be reminded by hooks of the potential for education to be a 'practice of freedom' (hooks, 1994, p. 13) while the authors in this special issue help us to understand how and why we have lost sight of this.

The articles in this special issue offer some powerful provocations. They incite a renewed interest in Foucault's work in its entirety and encourage us to make use of it, and even to re-read it (Golder, 2013), not just to revisit our understandings of our history, but as Axelsson points out, in order to see that the present is just as strange as the past. They draw attention to the particular 
contribution of the Nordic countries to the debates about normality and abnormality that, although reflecting differences between countries, is both significant and valuable as a whole. They add sophistication to understandings of constructions of the deviant child and the 'knowledge monopoly' (Ydesen et al., 2013, p. 120) of these constructions and of their validation through testing and diagnosis. Finally, and perhaps most importantly, these contributions help us to recognize that a different kind of education could possibly help us to realize the freedoms for which Foucault exhorted us to strive.

\section{References}

Artiles, A., Kozleski, E., Trent, S., Osher, D. \& Ortiz, A. (2010). Justifying and explaining disproportionality, 1968-2008: A critique of underlying views of culture. Exceptional Children, 76(3), 279-299.

Beach, D. \& Dovemark, M. (2011). Twelve years of upper-secondary education in Sweden: the beginnings of a public neoliberal hegemony? Educational Review, 63(3), 313-327.

Bogard, W. (2000). Smoothing machines and the constitution of society. Cultural Studies, 14(2), 269-294.

Foucault, M. (1976). Mental illness and psychology. Berkeley/Los Angeles, CA: University of California Press.

Foucault, M. (1977). Discipline and punish: The birth of the prison. London: Penguin.

Gillborn, D. (2010). Reform, racism and the centrality of whiteness: Assessment, ability and the 'new eugenics'. Irish Educational Studies, 29(3), 231-252.

Gillborn, D. (forthcoming). Genetics, race, intelligence \& education: The hidden racism of the new geneism.

Golder, B (Ed.) (2013). Rereading Foucault: On law, power and rights. Abingdon, UK: Routledge.

Harwood, V. \& Allan, J. (2014). Psychopathology at school: Theorising mental disorders in education. London: Routledge.

Hooks, b. (1994). Teaching to transgress. New York/London: Routledge.

Hughes, B. (2005). What can a Foucauldian theory contribute? In S. Tremain (Ed.) Foucault and the government of disability (pp. 78-92). Ann Arbor, MI: University of Michigan Press.

López, I. (2014). Dog whistle politics: How coded racial appeals have reinvented racism $\&$ wrecked the middle class. Oxford: Oxford University Press.

Martin, L., Gutman, L. \& Hutton, P. (1988). Technologies of the self: A seminar with Michel Foucault. Amherst, MA: University of Massachusetts press

McWhorter, L. (2005). Foreword. In S. Tremain (Ed.) Foucault and the government of disability (pp. xiii-xvii). Ann Arbor, Ml: University of Michigan Press.

Rajchman, J. (1995). Foucault ten years after. Michel Foucault: J'Accuse. A Journal of Culture/Theory/Politics, 25, 14-20.

Sahlberg, P. (2007). Education policies for raising student learning: The Finnish approach. Journal of Educational Policy, 22(2), 173-197. 
Sjöberg, L. (2014). The construction of the ideal pupil - teacher training as a discursive and governing practice. Education Inquiry, 5(4), 517-533.

Stiggins, R. J. (2002). Assessment crisis: the absence of assessment FOR learning. Phi Delta Kappan, 83(10), 758-765. doi: 10.1177/003172170208301010

Tomlinson, S. (2012). The irresistible rise of the SEN industry. Oxford Review of Education, 38(3), 267-286.

Vallberg Roth, A. \& Månsson, A. (2011) Regulated childhood equivalence with variation. Early Years. An International Research Journal, 29(2), 177-190.

Waitoller, F., Artiles, A. \& Cheney, D. (2010). The miner's canary: A review of overrepresentation research and explanations. The Journal of Special Education, 44(1), 29-49.

Ydesen, C. (2011). The rise of high stakes testing in Denmark, 1920-1970. Frankfurt: Peter Lang Verlag.

Ydesen, C., Ludvigsen, K. \& Lundahl, C. (2013). Creating an educational testing profession in Norway, Sweden and Denmark, 1910-1960. European Educational Research Journal, 12(1), 120-138. 